Tersedia online di: http://ejournal-balitbang.kkp.go.id/index.php/JP
e-mail:jurnalpari@gmail.com
JURNAL PARI
Volume 3 Nomor 2 Desember 2017
p-ISSN: 2502-0730
e-ISSN : 2549-0133

\title{
PENDEKATAN MIND MAPPING DALAM PENYUSUNAN STRATEGI KOMUNIKASI HASIL LITBANG
}

Approching of Mind mapping in developing of comunication strategy in Agency of Marine Research and Development

\section{KASMAWATI}

Sekretariat Badan Riset dan Sumber Daya Manusia Kelautan dan Perikanan

Diterima tanggal : 3 Oktober 2017 diterima setelah perbaikan : 1 November 2017 disetujui terbit : 4 Desember 2017

\begin{abstract}
ABSTRAK
Komunikasi merupakan cara untuk menyampaikan pesan atau informasi kepada masyarakat. Penyampaian pesan/informasi yang benar dapat tersusun dengan strategi komunikasi yang baik dan benar salah satu metode yang digunakan adalah menggunakan Mind Mapping. Metode mind mapping jarang diketahui dan juga digunakan oleh instansi pemerintah, dan diharapkan dapat membantu dalam penyusunan perencanaan/ program momunikasi untuk membangun citra positif Kementerian Kelautan dan Perikanan dan BRSDM khususnya.
\end{abstract}

Kata Kunci: Komunikasi, Informasi, Pesan, Mind Mapping

\section{ABSTRACT}

Comunication is a way to deliver messages or information to the public. The correct delivery of messages / information can be structured with good and right communication strategies. One of the methods used is Mind Mapping. The mind mapping method is rarely known and is also used by government agencies.

Keywords: Communication, Information, Messege, Mind Mapping. 


\section{PENDAHULUAN}

Pada era globalisasi saat ini, penyelenggaraan pelayanan pada suatu instansi mulai mengembangkan dimensi keterbukaan, mudah diakses, accountable dan transparan yang mengarah pada "Good Governance"

Dalam suatu organisasi khususnya pemerintahan sangat dituntut dalam pencapaian suatu hasil dalam mencapai tujuan yang diinginkan. Untuk mencapai tujuan tersebut, dalam perencanaan dan manajemen suatu organisasi diperlukan peran komunikasi dalam penyampaian maksud yang diharapkan agar sampai kepada khalayak, diterima, dan menerapkan informasi tersebut. Kemajemukan masyarakat sehingga penyampaian informasi perlu dikemas secara baik dan benar.

Beberapa pengertian atau teori tentang komunikasi diantaranya Bernard Barelson \& Garry A. Steiner Komunikasi adalah proses transmisi informasi, gagasan, emosi, keterampilan dan sebagainya dengan menggunakan simbol-simbol, kata-kata, gambar, grafis, angka, dsb. Sedangkan Onong Uchjana Effendy.

Komunikasi adalah proses penyampaian pesan oleh seseorang kepada orang lain untuk memberitahu, mengubah sikap, pendapat, atau perilaku, baik secara lisan (langsung) ataupun tidak langsung (melalui media)

Menurut Thomas M. Scheidel, Manusia pada umumnya berkomunikasi untuk menyatakan dan mendukung identitas-diri dan untuk membangun interaksi sosial dengan orang-orang yang berada di sekitar kita serta untuk mempengaruhi orang lain untuk berpikir, merasa, atau bertingkah seperti yang kita harapkan.

Pertama yang perlu dilakukan adalah memperjelas secara keseluruhan tujuan komunikasi, yakni hal yang diinginkan dan informasi apa yang dibutuhkan stakeholders. Tiga hal umum dari tujuan komunikasi antara lain memberikan informasi/pemahaman, melakukan persuasi, atau melakukan klarifikasi atas suatu isu.

Komunikasi dengan khalayak tidaklah sesederhana sebagaimana dikemukakan olej Sharon dan Weaver. Komunikasi dengan khalayak sasaran (target public) yang diinginkan pada kenyataannya bahkan jauh lebih rumit.

Begitu pentingnya komunikasi yang baik agar apa yang ingin disampaikan dapat diterima, dimengeri/dipahami, maka Komunikasi seharusnya direncanakan secara strategis, namun di tahap awal, pada praktiknya banyak instansi yang kurang memerhatikan atau kurang memahami akan pentingnya strategi komunikasi.

Dalam merumuskan peran komunikasi tersebut maka perlukan cara atau tekhnik komunikasi yang baik yaitu strategi komunikasi. Strategi komunikasi yang efektif, dan efisien sangat beperan penting sebagai langkah awal untuk merumuskan suatu kebijakan atau perencanaan memberikan kontribusi yang luar biasa pada keberhasilan dalam suatu instansi.

Morisson (2010) berpendapat bahwa berpikir strategis meliputi tindakan memperkirakan atau membangun tujuan masa depan yang diinginkan menentukan kekuatan-kekuatan yang akan membantu atau yang akan menghalangi tercapainya tujuan yang diinginkan.

Menurut Onong Uchjana Efendi, strategi komunikasi merupakan panduan dari perencanaan komunikasi (communication planning) dan manajemen (communications management) untuk mencapai suatu tujuan. Untuk mencapai tujuan tersebut strategi komunikasi harus dapat menunjukkan bagaimana operasionalnya secara taktis harus dilakukan, dalam arti kata bahwa pendekatan (approach) bisa berbeda sewaktuwaktu tergantung dari situasi dan kondisi". (1981 : 84).

Oleh karena itu, penyusunan strategi komunikasi sebagai panduan perencanaan komunikasi (comunication planning) pada suatu instansi menggunakan pendekatan yang berbeda tergantung pada situasi dan kondisi organisasi tersebut. Fungsi strategi kehumasan sangat menentukan berhasil tidaknya kegiatan komunikasi dalam menyampaikan pesan untuk mencapai tujuan yang akan dicapai.

Strategi komunikasi yang direncanakan akan lebih tepat sasaran (baik target, audiensi, serta pesan akan terklarifikasi, sebelum memutuskan media apa yang dipilih untuk menyampaikan pesan komunikasi) dalam pencapaian tujuan hasil yang diharapkan.

Dalam penyusunan dan merumuskan strategi komunikasi, perlu terlebih dahulu mengidentifikasi dan memetakan isu-isu strategis. Isu strategis adalah kondisi atau hal yang harus diperhatikan atau dikedepankan dalam perencanaan pembangunan. Tahapan tersebut 
merupakan bagian dari proses dan tujuan dalam penyusunan Strategi Komunikasi. Pembahasan isu strategis yang kemudian dipetakan, salah satunya menggunakan program mind mapping.

Program mind mapping sekarang ini banyak berkembang salah satunya dalam proses belajar mengajar bagi para guru/dosen dan pelajar/ mahasisawa. Mind Mapping dapat menstimulus otak kiri dan otak kanan secara sinergisyang bermanfaat dalam proses pembelajaran terutama dalam keterampilan mencatat dan mengingat.

Mind mapping adalah suatu proses pemetaan dengan menghubungkan konsep konsep dari cabang cabang untuk membentuk korelasi konsep menuju suatu pemahaman agar dapat dimengerti oleh pembuatnya.

Memperhatikan uraian diatas, tulisan ini mengambil permasalahan tentang pemanfaatan Mind Mapping terutama dalam memetakan hasil penelitian kelautan dna perikanan, sebagai data awal dalam penyusunan strategi kehumasan, dan juga mempermudah dalam penyususnanprogram dna penyusunan penelitian di BRSDKP.

\section{Rumusan Masalah}

Pada awalnya Badan Penelitian dan Pengembangan Kelautan dan Perikanan (Balitbang KP) merupakan unit eselon 1 di Kementerian Kelautan dan Perikanan (KKP) dalam cita citanya ingin menjadi center of excellence (pusat kepakaran) bidang kelautan dan perikanan tahun 2019 sebelum bergabung menjadi Badan Riset dan Sumber Daya Manusia Kelautan dan Perikanan (BRSDMKP).

Tantangan yang dihadapi sampai saat ini diantaranya stigma negatif yang melekat bahwa hasil penelitian dalam melakukan kegiatan litbang tanpa melihat kebutuhan eselon 1 di lingkungan KKP. Selain itu, adanya pandangan masyarakat tentang hasil litbang KP yang dinilai belum memadai, hingga belum teradopsi secara baik oleh masyarakat kelautan dan perikanan. Untuk itu perlu dilakukan langkah-langkah terobosan yang kiranya mampu membangun kepercayaan dan kebanggaan publik terhadap organisasi riset di KKP.

Untuk itu strategi kehumasan dibutuhkan untuk mengatasi permasalah diatas, sehingga dapat membangun citra penelitian kelautan dan perikanan Indonesia yang dapat diperhitungkan.
Berdasarkan latar belakang diatas maka dapat didefinisikan permasalahan untuk BRSDMKP bahwa pentingnya penyusunan mind mapping yang tepat dalam penyusunan strategi komunikasi BRSDMKP. Dalam penyusunan strategi kehumasan banyak belum menggunakan program mind mapping stakeholders. Informasi yang disusun mencerminkan dengan tepat bagaimana fungsi otak dalam serial untuk dihubungkan secara linier (Fahruddin, 2015).

\section{Tujuan}

Penggunaan mind mapping cukup efektif dalam penyusunan program, tujuan dan arah kebijakan. Mind mapping sangat penting digunakan dalam mengelola/mengumpulkan isu strategis untuk penyusunan konsep strategi komunikasi. Penyusunan mind mapping yang tepat dapat membantu membuat perencanaan dan pemecahan masalah.

Hasil dari penggunaan maind mapping dapat dijadikan referensi bagi penyusun program atau perencanaan.

Data penyusunan mind mapping merupakan hasil-hasil penelitian kelautan dan perikanan yang ada di Badan Riset dan Sumber Daya Manusia Kelautan dan Perikanan.

\section{Manfaat Tulisan}

Hasil penulisan ini dapat memberikan kontribusi kepada fungsional humasdi lingkungan Kementerian Kelautan dan Perikanan khususnya, juga sebagai bahan referensi atau contoh dalam membuat Mind Mapping (MM) pada program MM yang tersedia. Hasil ini kemudia menjadi model pemetaan hasil dan bermanfaat sebgai sumber pengetahuan dan acuan dalam melakukan komunikasi pada suatu instansi.

\section{PEMBAHASAN}

Anthony Peter Buzan, penemu metode Mind Mapping yang karyanya sangat berpengaruh dalam sejarah dunia-pendidikan, dan beliau lebih dikenal dengan nama Tony Buzan. Menurut sang pengembang, Tony Buzan, mind mapping adalah suatu teknik mencatat yang menonjolkan sisi kreatifitas sehingga efektif dalam memetakan pikiran (Tony Buzan dan Barry, 2004).

Mind maping adalah cara mengembangkan kegiatan berpikir ke segala arah, menangkap berbagai pikiran dalam berbagai sudut. Mind 
maping mengembangkan cara berpikir divergen dan berpikir kreatif. Mind mapping yang sering kita sebut dengan peta konsep adalah alat berpikir organisasional yang sangat hebat yang juga merupakan cara termudah untuk menempatkan informasi ke dalam otak dan mengambil informasi itu ketika dibutuhkan (Tony Buzan , 2008:4).

Menurut Tony Buzan, Mind Maping dapat membantu kita untuk banyak hal seperti : merencanakan, berkomunikasi, menjadi lebih kreatif, menyelesaikan masalah, memusatkan perhatian, menyusun dan menjelaskan pikiranpikiran, mengingat dengan baik, belajar lebih cepat dan efisien serta melatih gambar keseluruhan.

Manfaat mind mapping adalah tema umum terdefinisi sangat jelas, efesiensi waktu dalam mempelajari suatu informasi, meningkatkan kemampuan untuk mengingat sesuatu lebih utuh, detail, mudah dipahami/dikuasai. Sehingga dapat membantu lebih fokus dalam menyaring informasi dapa saja, dalam bentuk yang sederhana tetapi teratur.

Secara umum mind map adalah "peta" dari pikiran manusia yang menggunakan assosiasi, koneksi dan memicu koneksi untuk merancang ide ide lebih lanjut. Ide-ide tersebut diekstrak menjadi sesuatu yang terstruktur dan terlihat.

Cara kerja mind mapping seperti cara kerja otak manusia, yang berhubungan langsung dengan otak bawah sadar sehingga mudah diingat. Dalam proses pemetaan melibatkan beberapa kombinasi, baik warna, citra dan visual (gambar/ foto) yang secara signifikan dapat meningkatkan daya ingat dari pada metode konvensional, dengan cabang-cabang dan gaya tata letaknya.

\section{LANGKAH LANGKAH PEMBUATAN MIND MAPPING}

Langkah awal dalam pembuatan Mind Mapping adalah;

A. Pengumpulan data pada hasil penelitian di lingkup Balitbang KP berasal dari Pengumpulan data dilakukan dengan cara:

1. studi dokumen berupa:

- Laporan berkala/tahunan;

- Buku atau litertur lain;

- Kliping pemberitaan;

- Peraturan dn peundang-undangan;

- Dokumentasi (foto/video);
2. Wawancara, dengan narasumber yang berkompeten (Kepala Pusat/Balai Besar/peneliti). Beberapa isu strategis merupakan hasil pengambil keputusan politis, secara teknis dan administratif akan lebih mudah dikerjakan dengan nilai dasar nilai dasar organisasi.

B. Klasifikasi/Identifikasi Isu, Identifikasi dan pemetaan isu strategis Balitbang KP dikaitkan dengan pemetaan pemangku kepentingan di Badan Penelitian dan Pengembangan Kelautan dan Perikanan. hasil penelitian dan pengembangan kelautan dan perikanan dikelompokkan menjadi 4 isu sentral kelautan dan perikanan.

Tabel identifikasi Isu Sentral Satuan Kerja eks Balitbang KP.

\begin{tabular}{|c|c|}
\hline Satuan Kerja & Isu Sentral \\
\hline $\begin{array}{c}\text { Pusat Penelitian } \\
\text { dan Pengembangan } \\
\text { Perikanan }\end{array}$ & $\begin{array}{c}\text { Isu terkait } \\
\text { perikanan }\end{array}$ \\
\hline $\begin{array}{c}\text { Pusat Penelitian dan } \\
\text { Pengembangan Sumber } \\
\text { Daya Laut dan Pesisir }\end{array}$ & $\begin{array}{c}\text { Isu terkait } \\
\text { kelautan }\end{array}$ \\
\hline $\begin{array}{c}\text { Pusat Penelitian dan } \\
\text { Pengembangan Daya } \\
\text { Saing Produk dan } \\
\text { Bioteknologi KP }\end{array}$ & $\begin{array}{c}\text { Pengolahan } \\
\text { Produk dan } \\
\text { Bioteknologi }\end{array}$ \\
\hline $\begin{array}{c}\text { Pusat Penelitian Sosial } \\
\text { Ekonomi Kelautan dan } \\
\text { Perikanan }\end{array}$ & Sosial Ekonomi \\
\hline
\end{tabular}

Dari keempat isu tersebut dapat dilihat keterkaitan antara masing-masing isu yang bersinergi dan juga keterkaitan dengan unit eselon 1 lingkup KKP dari hasil-hasil penelitian di Balitbang KP.

C. Pembuatan Mind Mapping

a. Buat ide utama. Kalau sedang membaca buku maka tulislah judul buku yang sedang Anda baca di tengah-tengah kertas, pertegas dengan lingkaran. Tulis judul di tengah-tengah kertas dan beri gambar yang sesuai untuk memudahkan mengingat judul tersebut. Judul utama di buat sesuai unit kerja di Balitbang KP.

b. Buat cabang-cabang. Membuat beberapa bagian-bagian yang merupakan penjabaran dari ide utama. Cabang-cabang tersebut dibuat 
berdasarkan profil di masing-masing satker antara lain: Institusi, Regulasi, Kajian, Produk, Teknologi.

c. Tambahkan kata kunci. Membuat kata kunci dari penjabaran setiap cabangcabang dan catatlah sebagai ranting. Ketika menemukan sub-bagian dari pokok pembahasan sebelumnya buatlah ranting untuk menghubungkan dengan bagian sebelumnya. dan gunakan warna berbeda. Kemudian memberi label setiap cabang hanya dengan kata kunci.

d. Selanjutnya dari tiap cabang buat sub cabang untuk hal-hal yang saling berhubungan. Mengunakan garis-garis lengkung dan alur yang merupakan jawaban dari cabang utama berdasarkan kepentingan di masing-masing unit kerja.

\section{a. Mind Mapping Puslitbang Perikanan}

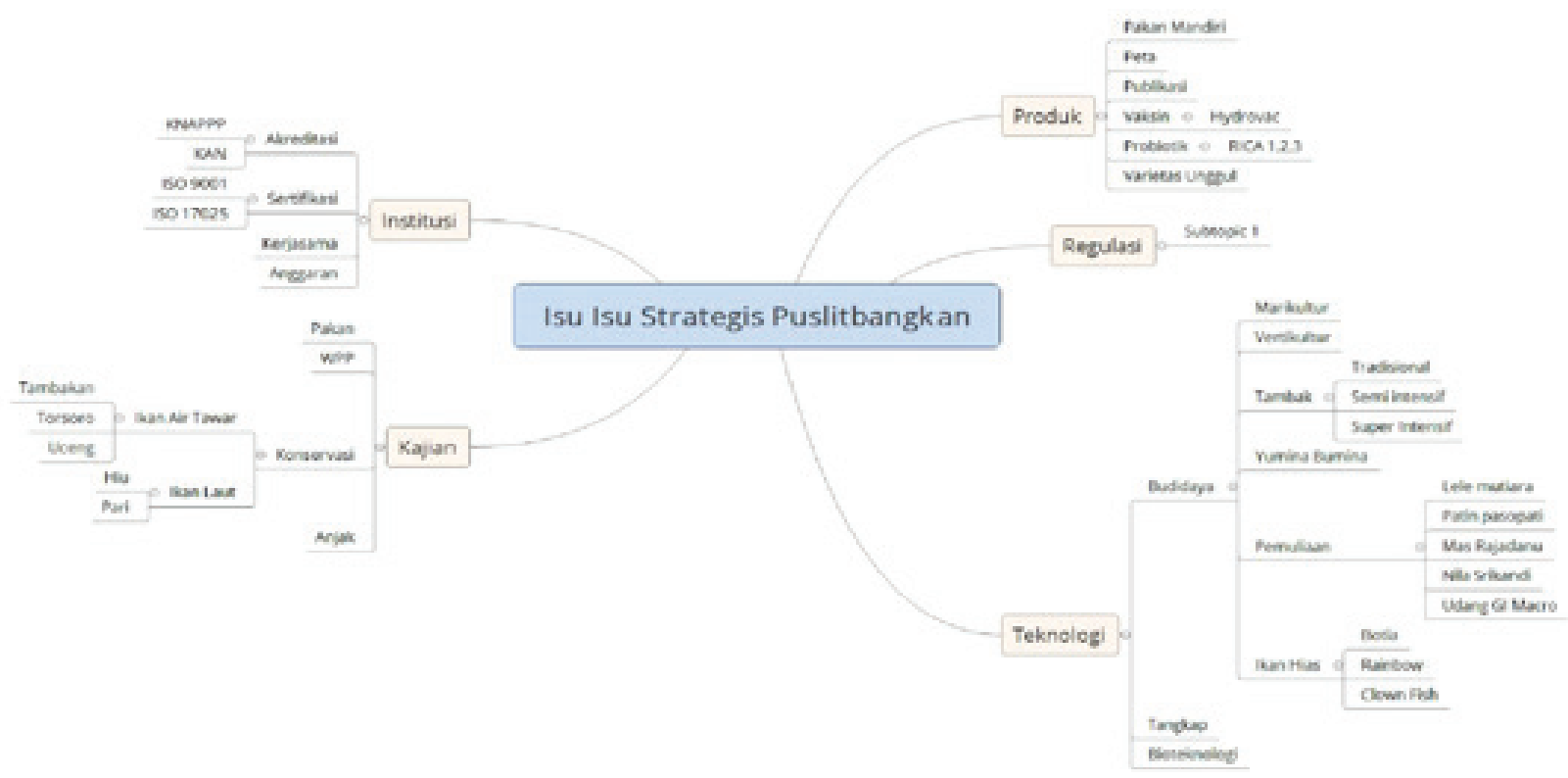

b. Mind Mapping P3SDLP

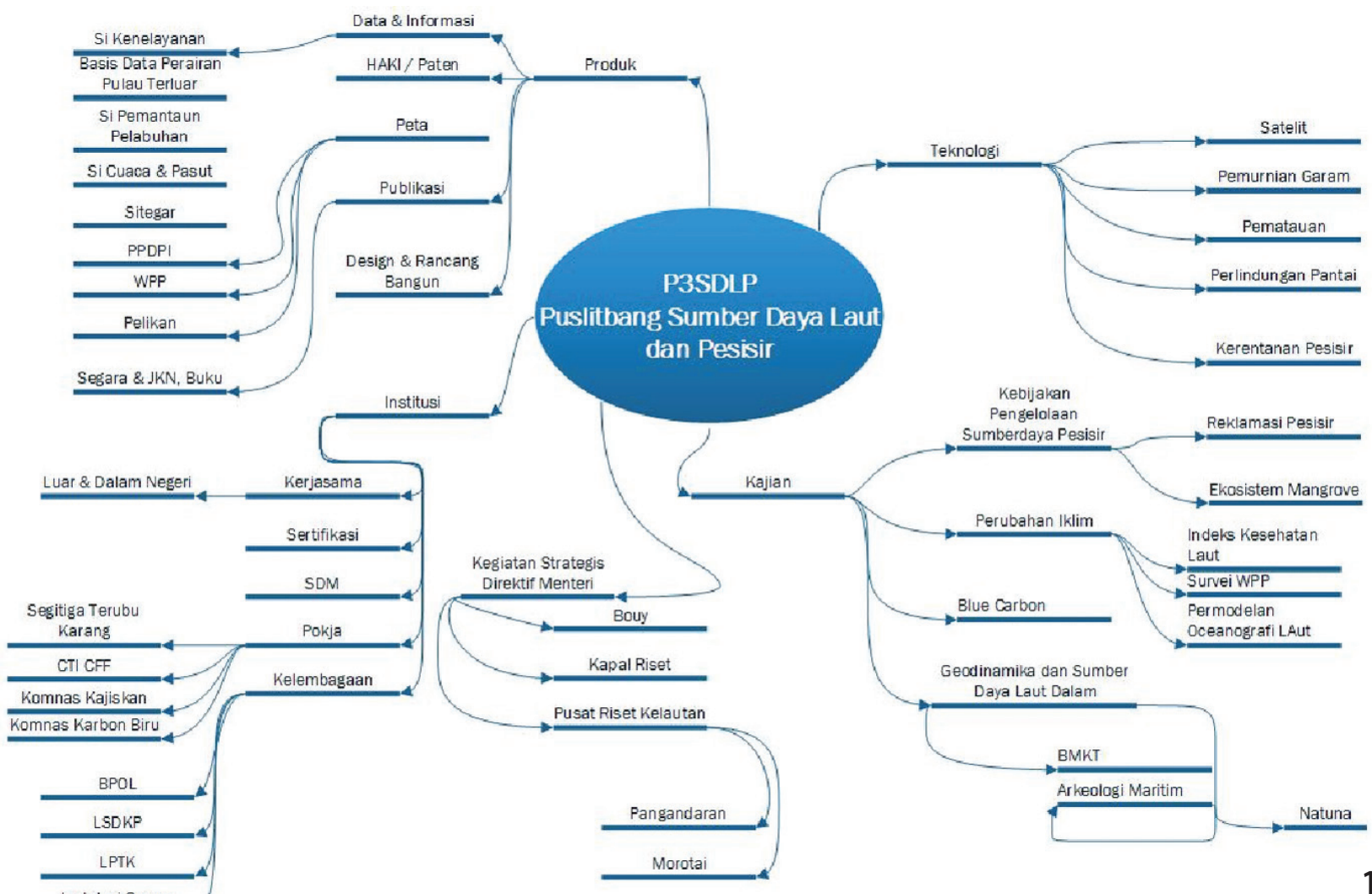

Copyrights (C) 2017, Jurnal Pari 


\section{c. Mind Mapping P3DSPBKP}

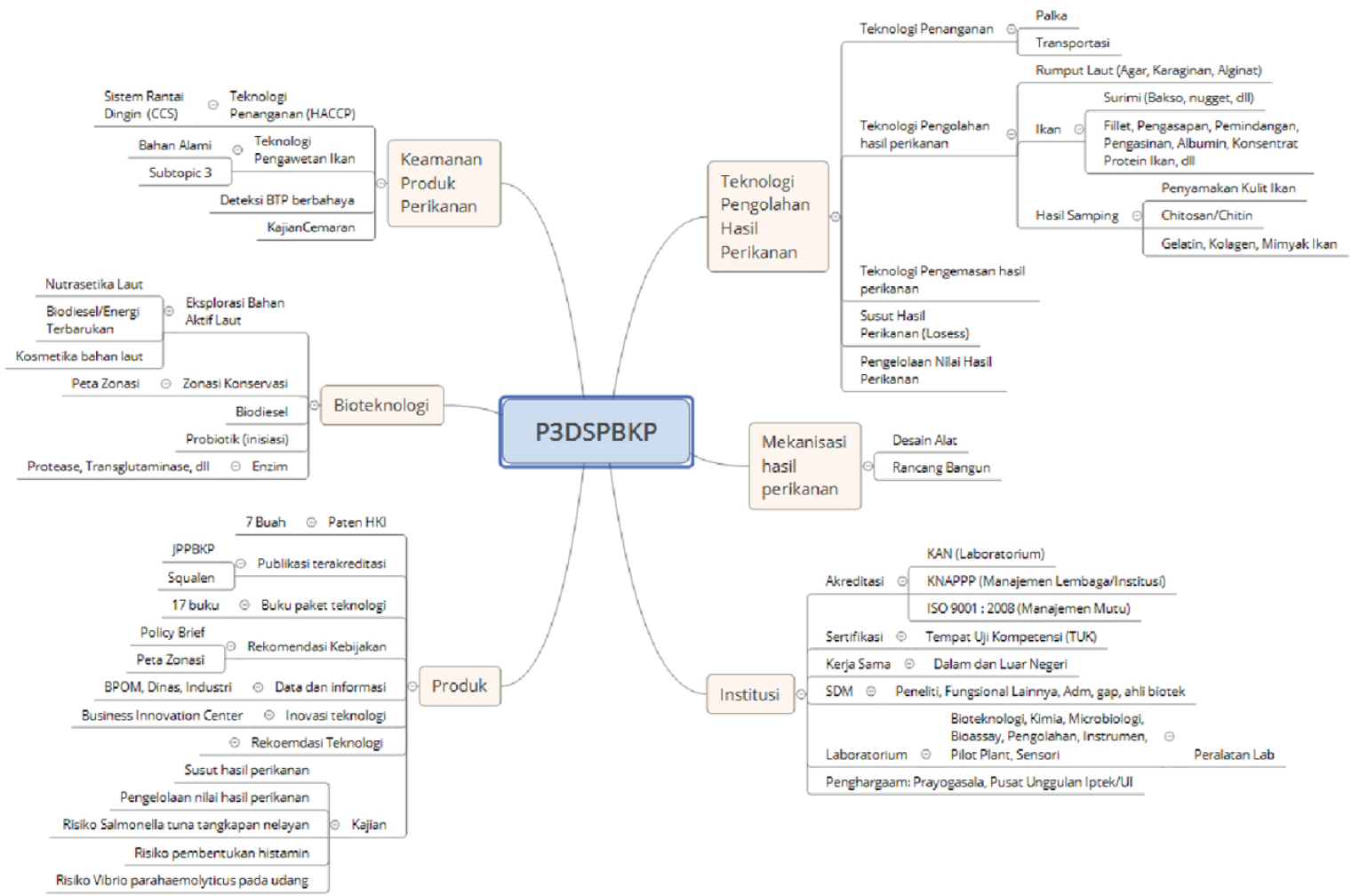

\section{d. Mind Mapping Puslit Sosial Ekonomi KP}

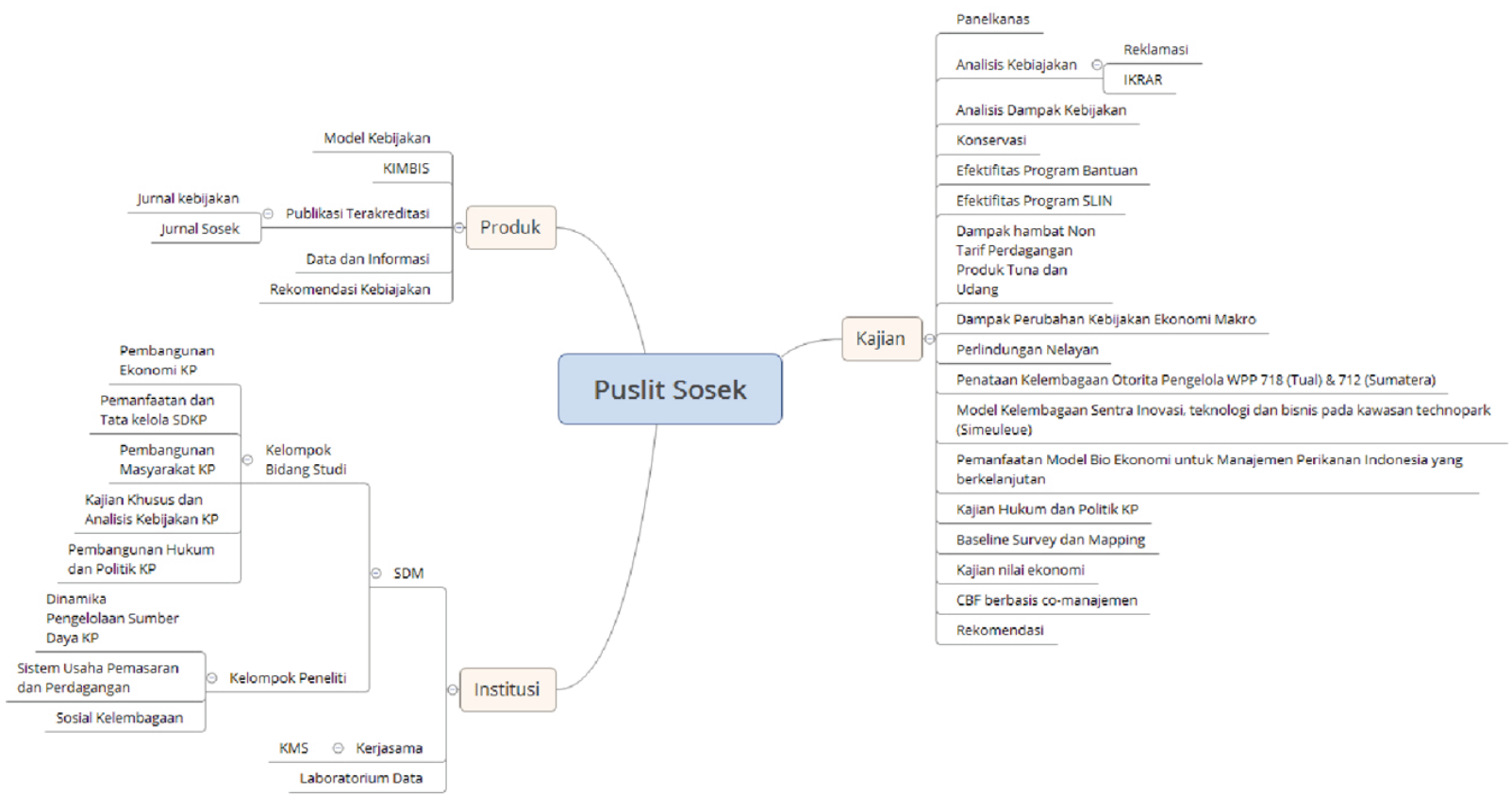




\section{PENUTUP}

\section{Kesimpulan}

Mind Mapping yang telah dibuat berdasarkan hasil penelitian kelautan dan perikanan pada organisasi Badan Riset dan Sumber Daya Manuasia Kelautan dan Perikanna (BRSDMKP) terdahulu yaitu Balitbang KP. BRSDMKP merupakan gabungan 2 eselon 1 antara Balitbang KP dan Badan Pengembangan Sumber Daya Manusia Kelautan dan Perikanan.

BRSDMKP dipandang perlu untuk melakukan penataan kembali menjadi lembaga riset terdepan melalui hasil penelitian berbasis kebutuhan dan stakeholder, pengembangan infrastruktur penelitian, penguatan data dan informasi, serta peningkatan kompetensi SDM.

Hasil penelitian perlu melakukan komunikasi secara sistematis dan terintegrasi dalam mengkomunikasikan upaya yang sedang dan akan dilakukan sehingga diharapkan proses penyusunan mind mapping hasil-hasil penelitian pada Badan Riset dan Sumber Daya Manusia Kelautan dan Perikanan dapat dijadikan acuan dalam penyusunan strategi komunikasi ke depan.

Unit eselon 1 lingkup KKP sebagai users/ stakeholders dari hasil-hasil penelitian yang dilakukan oleh para peneliti di BRSDMKP, dapat menggambil keputusan atau kebijakan dari hasil rangkuman mind mapp yang tepat dengan menggunakan struktur yang sederhana sehingga dapat dimengerti oleh pengguna (stakeholders).

\section{Saran}

Mind mapping ( $M M)$ ini sangat penting sebagai data awal dalam perumusan strategi kehumasan. Dengan menyatunya Balitbang KP dan BRSDMKP diharapkan mind mapping yang telah tersusun dapat dilengkapi kembali dan disempurnakan dan dikolaborasikan dengan unit kerja di bawah eks BPSDMKP. Dan juga dapat sebagai contoh bagi seluruh eselon 1 lingkup KKP lainnya dalam menyusun mind mapping.

\section{DAFTAR PUSTAKA}

Buzan, Tony. 2008. Buku Pintar Mind Map. Jakarta : PT. Gramedia Pustaka Utama.

Suyatno. 2009. Menjelajah Pembelajaran Inovatif. Sidoarjo: Masmedia Buana Pustaka.

Wilbur Schram, 1971. The Process and Effect of Mass Comunications, Univeersity of Illinois Press.

Morissan, MA, 2010, Manajemen Public Relation: Strategi Menjadi Humas Profesional. Jakarta: Kencana -Prenada Media Grup. 


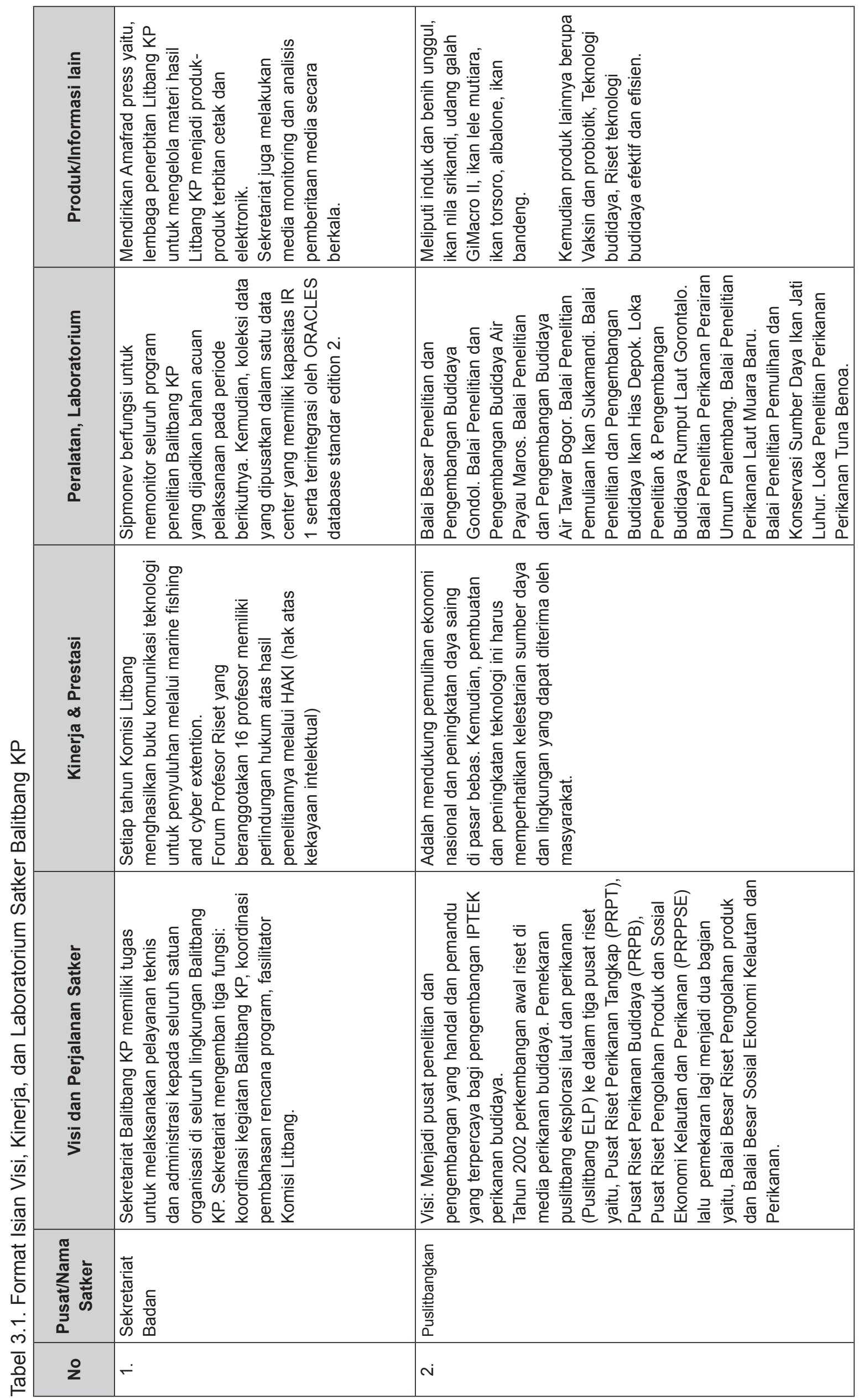




\begin{tabular}{|c|c|c|c|}
\hline 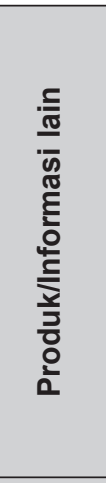 & 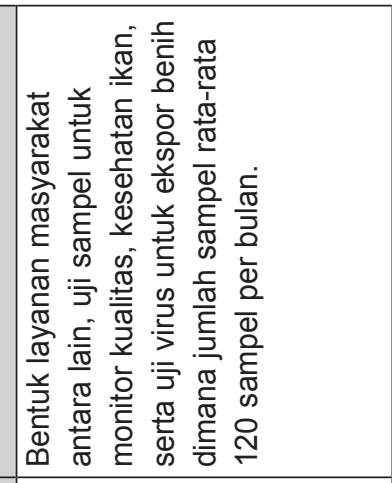 & 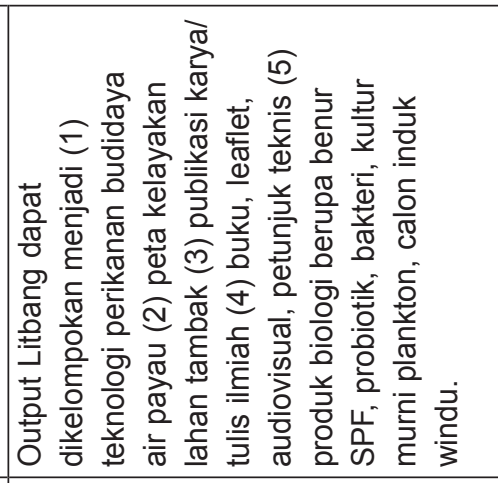 & 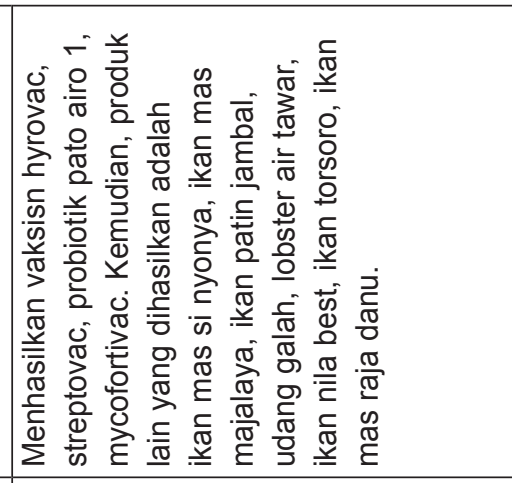 \\
\hline 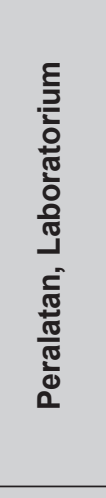 & 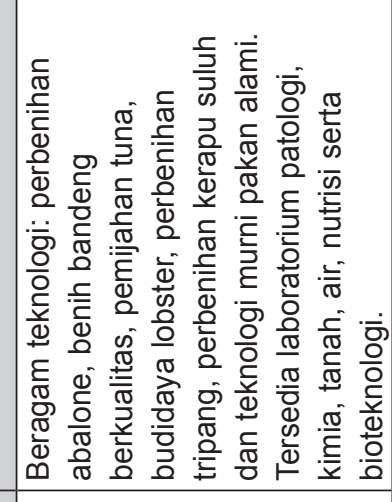 & 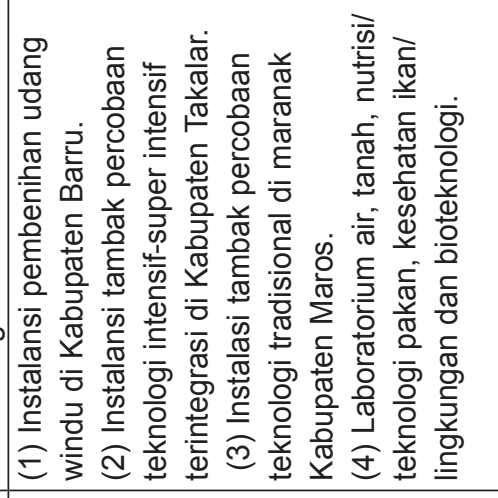 & 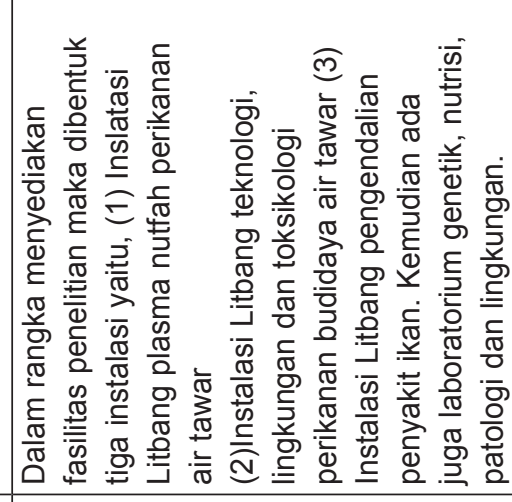 \\
\hline 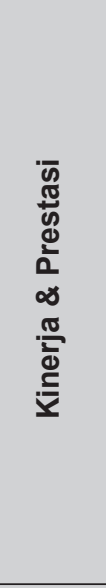 & 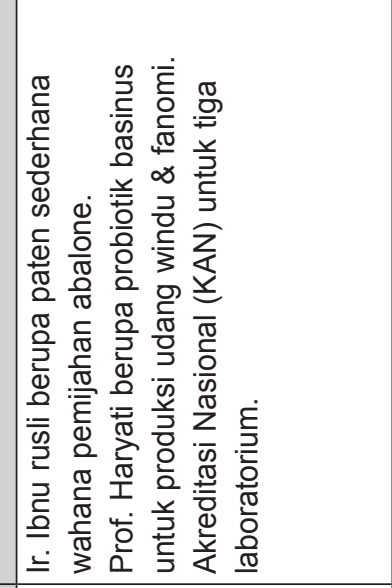 & 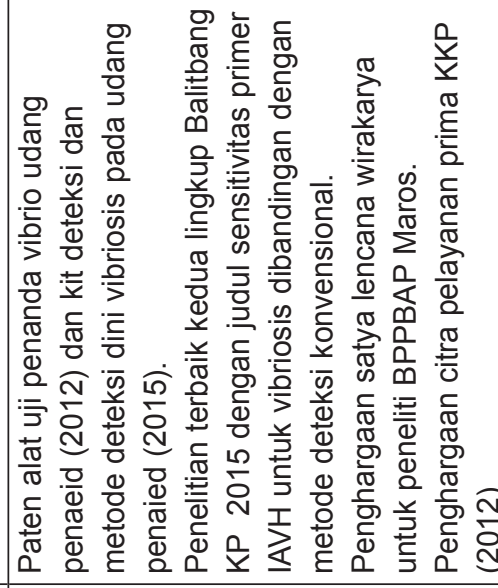 & 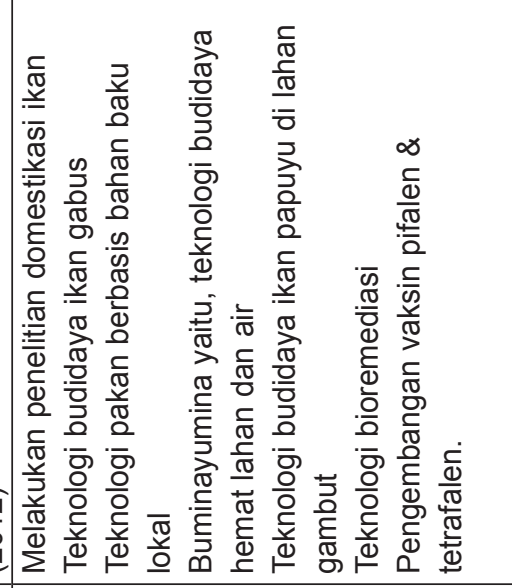 \\
\hline 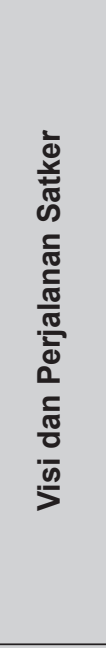 & 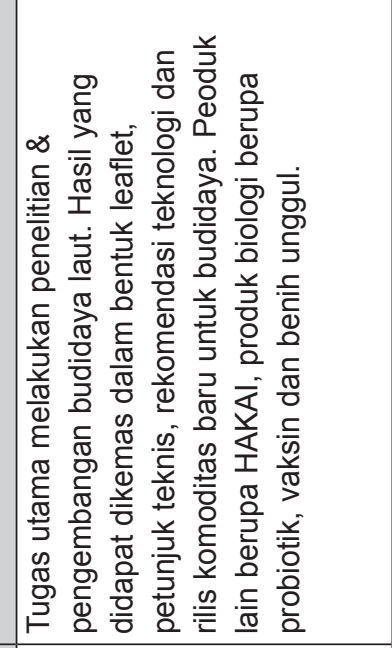 & 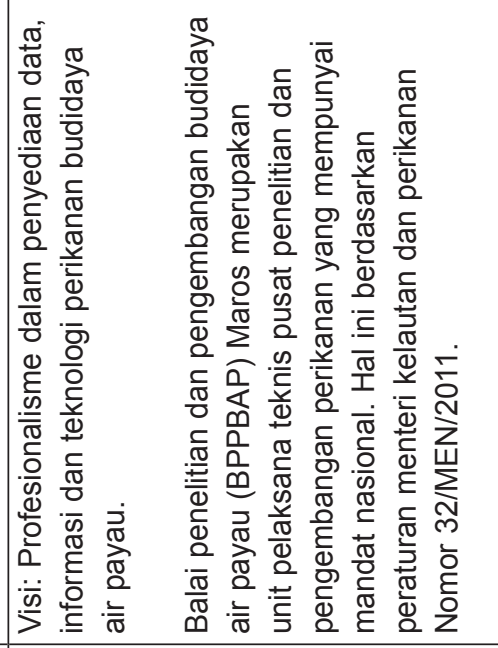 & 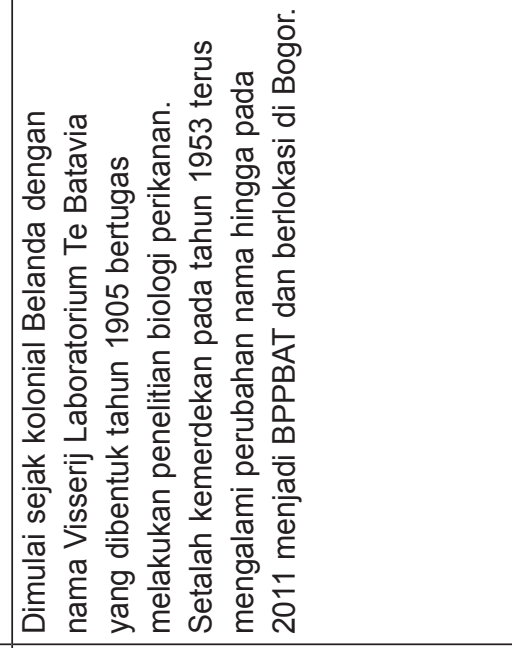 \\
\hline 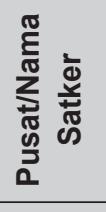 & 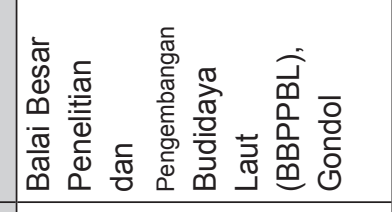 & 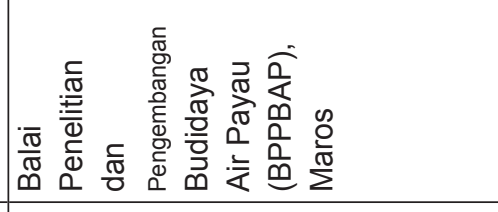 & 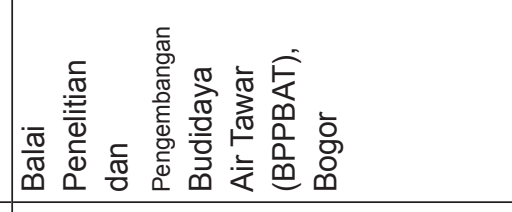 \\
\hline$\stackrel{\circ}{z}$ & $\dot{\bar{N}}$ & Ni & $\stackrel{m}{\sim}$ \\
\hline
\end{tabular}




\begin{tabular}{|c|c|c|c|}
\hline 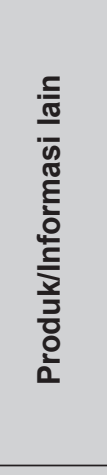 & 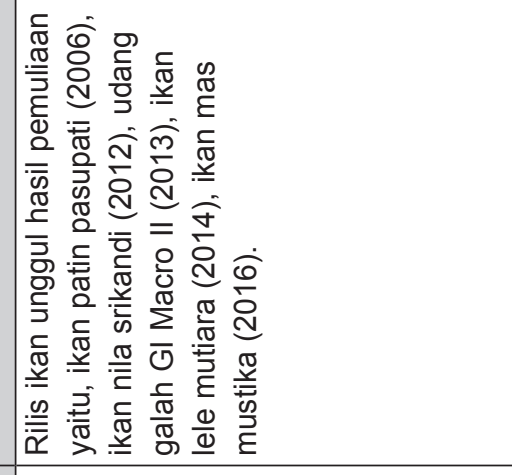 & 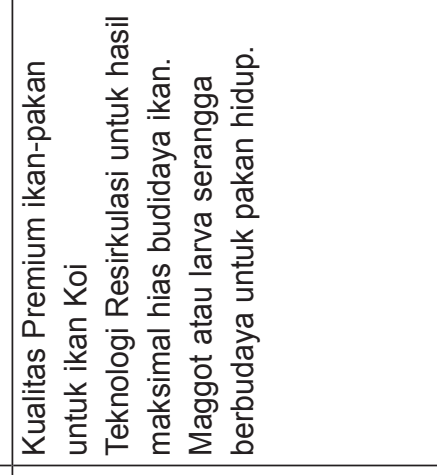 & 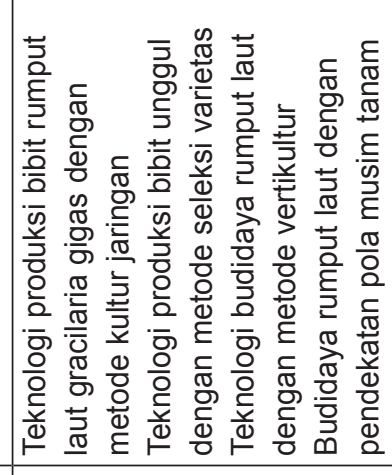 \\
\hline 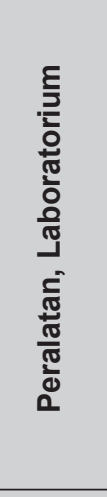 & 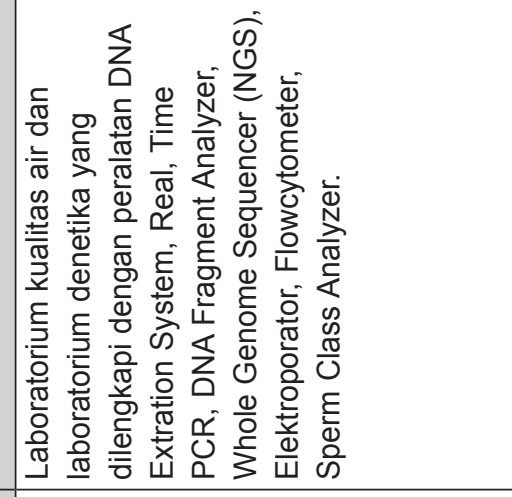 & 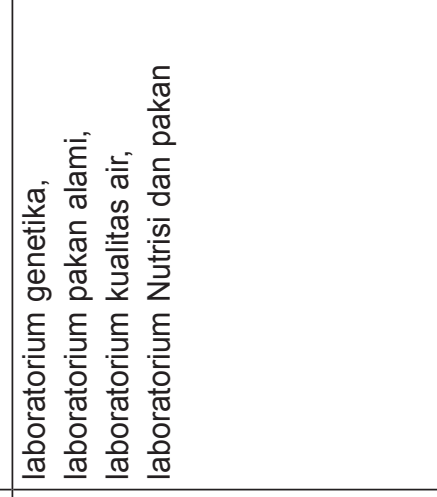 & 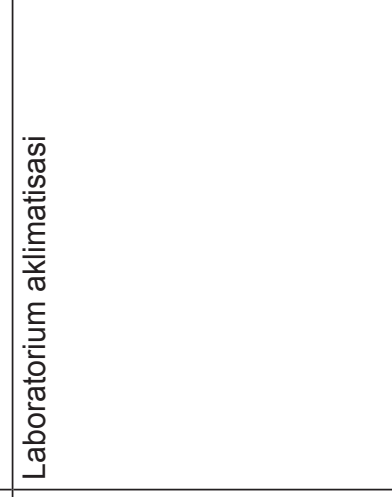 \\
\hline 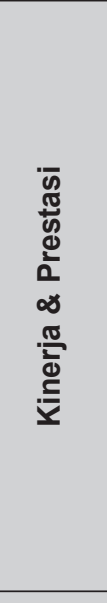 & 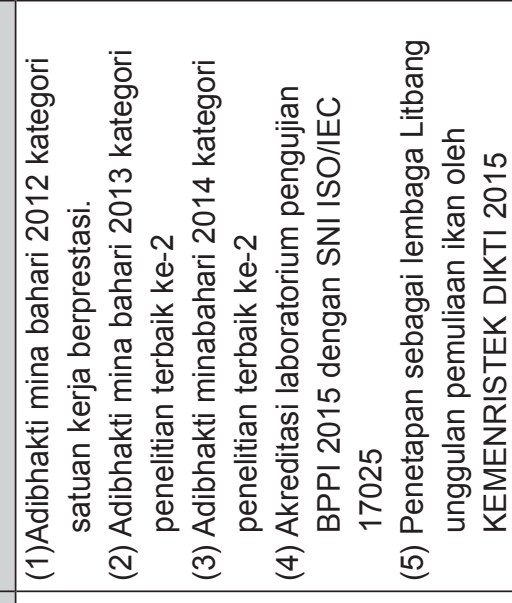 & 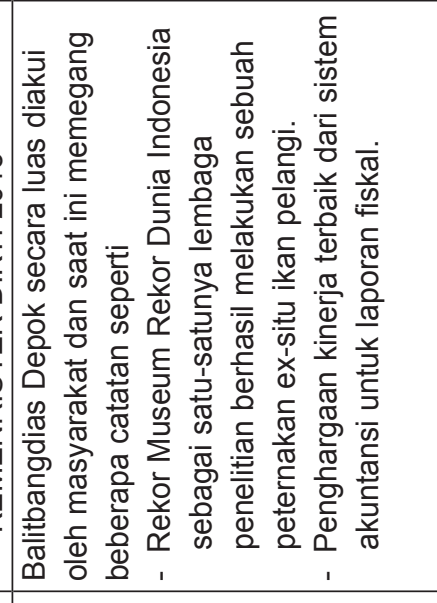 & 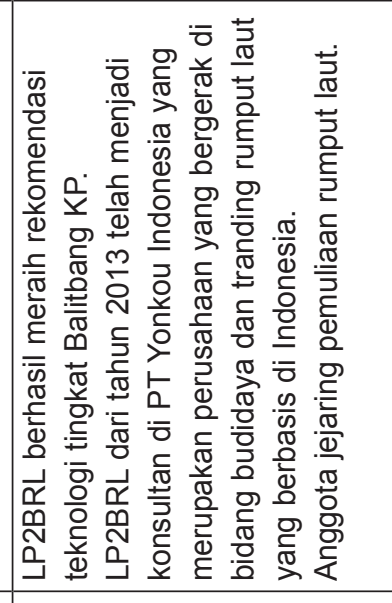 \\
\hline 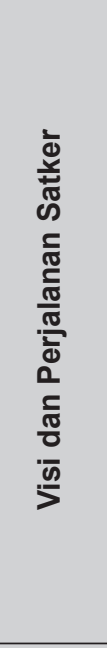 & 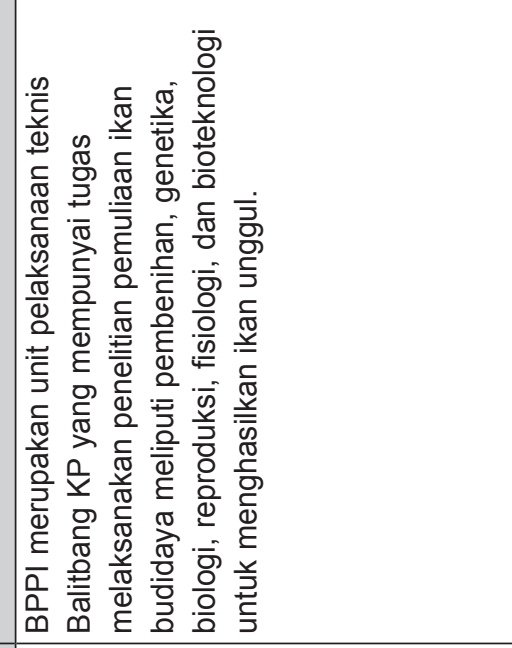 & 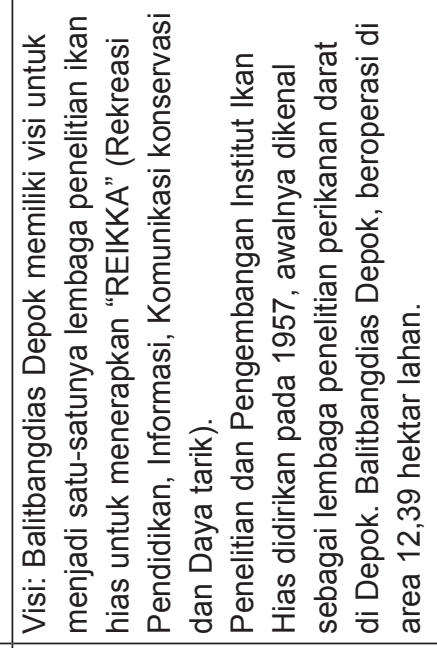 & 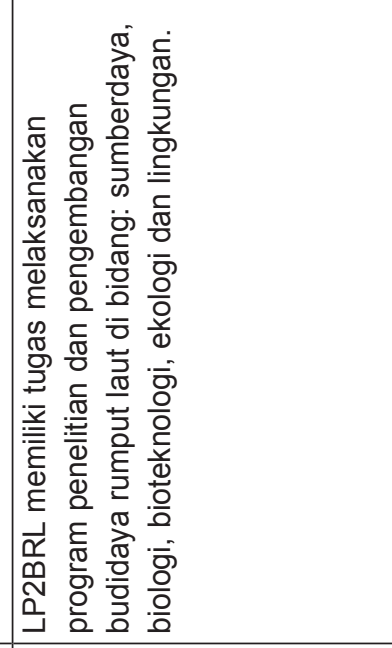 \\
\hline 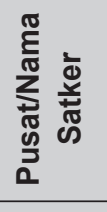 & 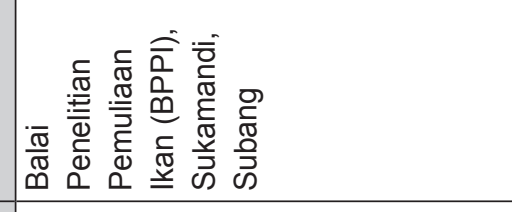 & 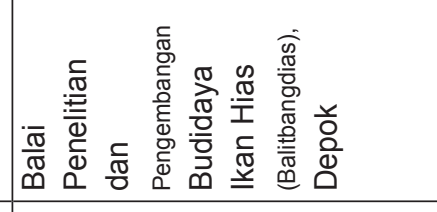 & 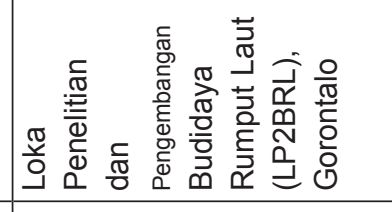 \\
\hline ㅇ & $\stackrel{\stackrel{ં}{N}}{\text { s. }}$ & นٌ & $\stackrel{\dot{\sim}}{\dot{\omega}}$ \\
\hline
\end{tabular}




\begin{tabular}{|c|c|c|}
\hline 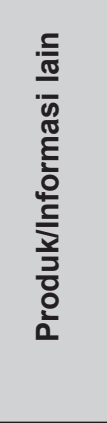 & 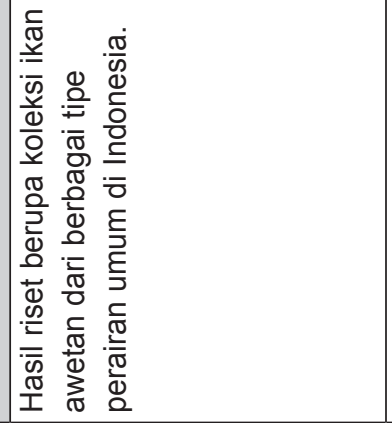 & 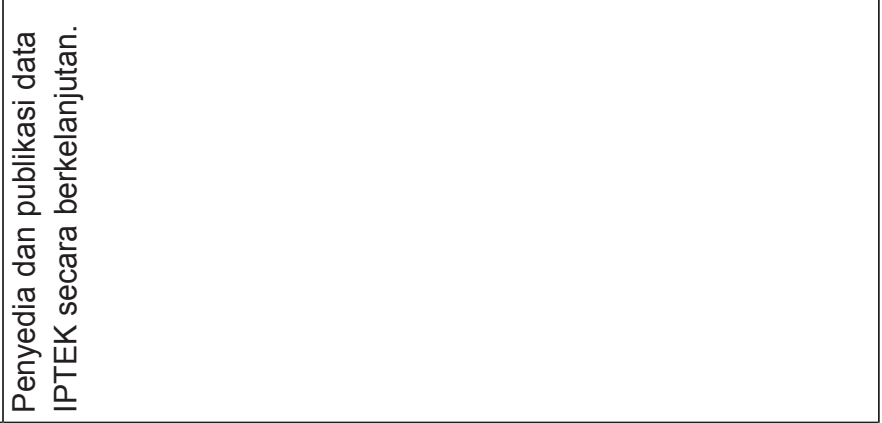 \\
\hline 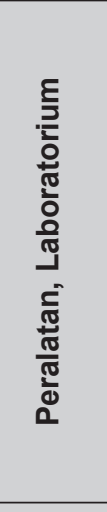 & 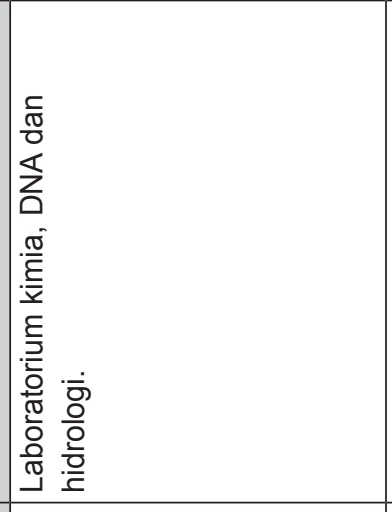 & 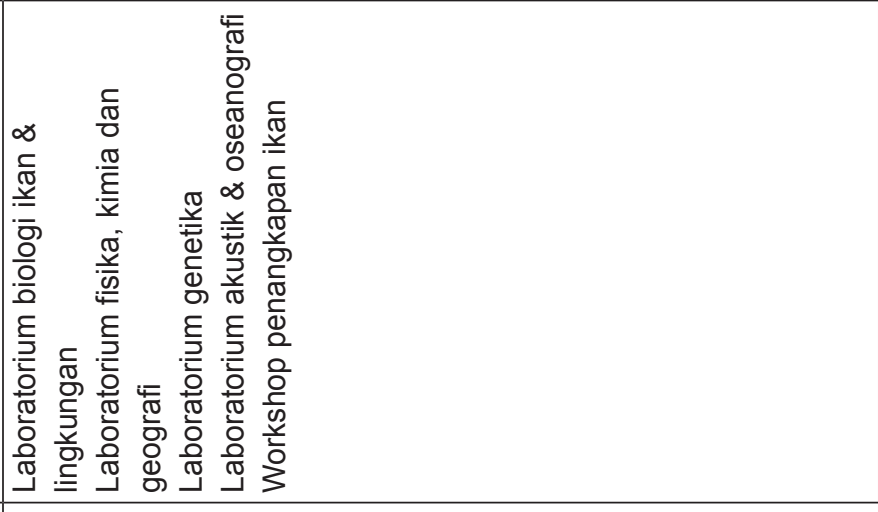 \\
\hline 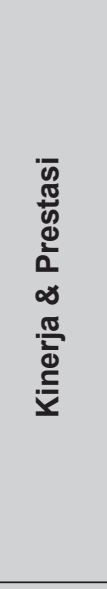 & 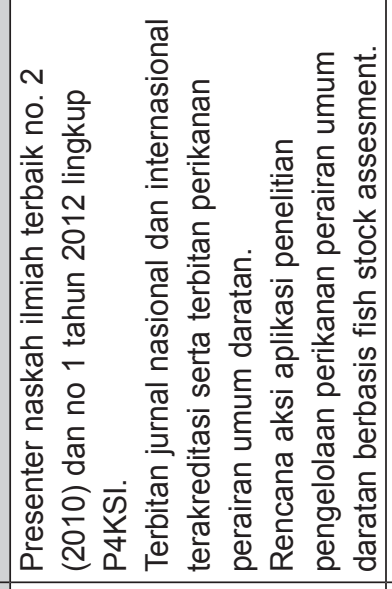 & 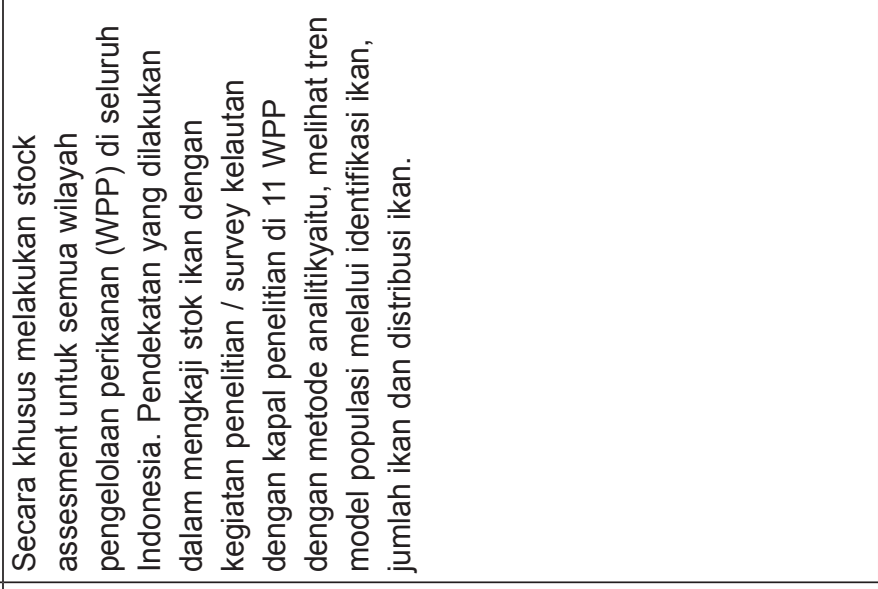 \\
\hline 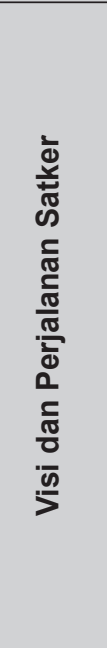 & 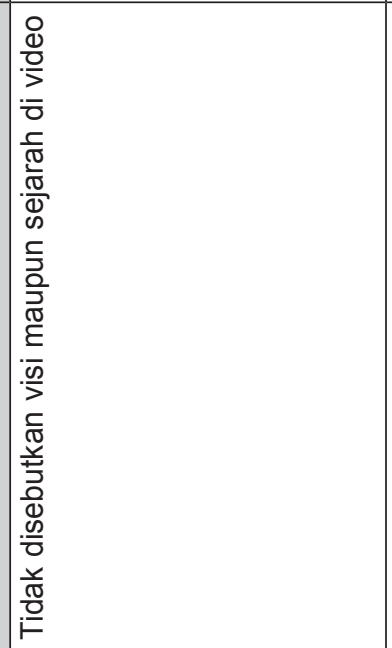 & 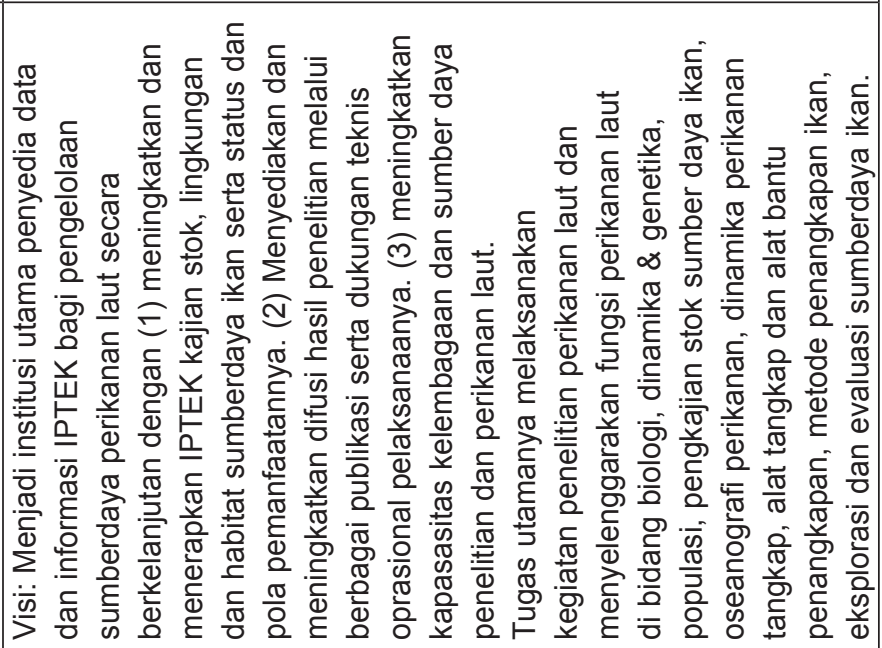 \\
\hline 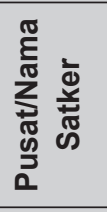 & 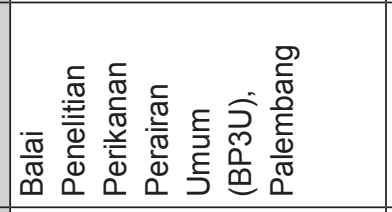 & 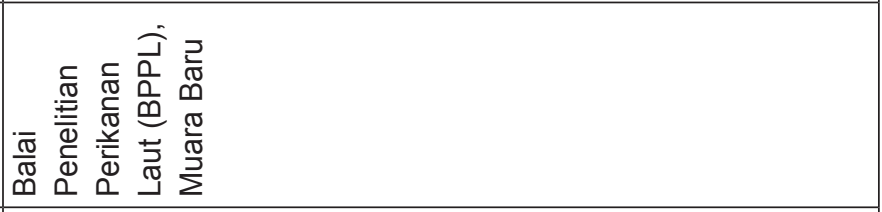 \\
\hline$\stackrel{0}{z}$ & $\hat{\sim}$ & \\
\hline
\end{tabular}




\begin{tabular}{|c|c|c|c|c|}
\hline 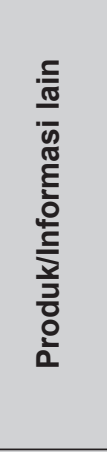 & 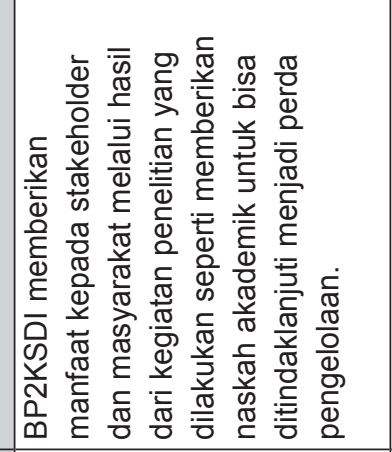 & \multicolumn{3}{|c|}{ 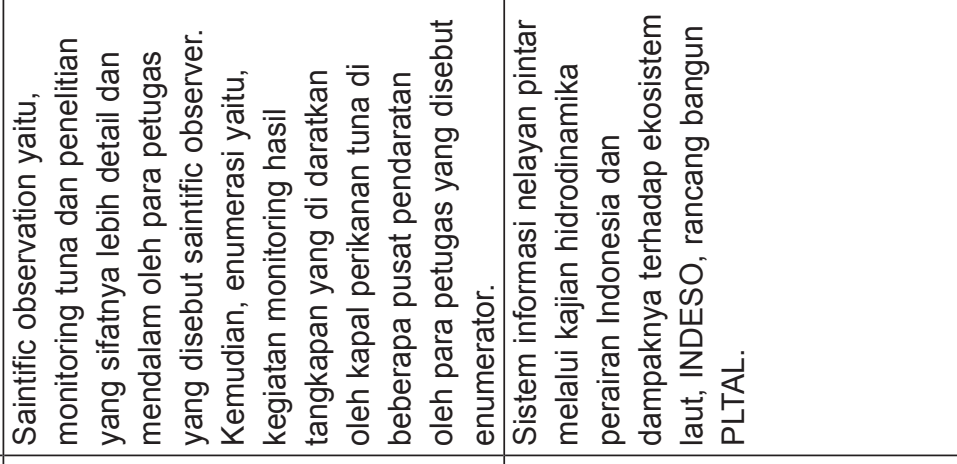 } \\
\hline 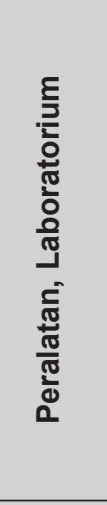 & 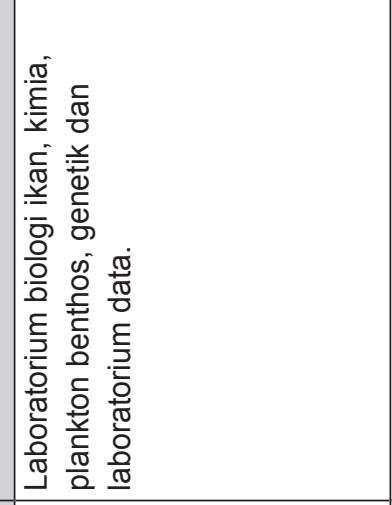 & \multicolumn{2}{|c|}{ 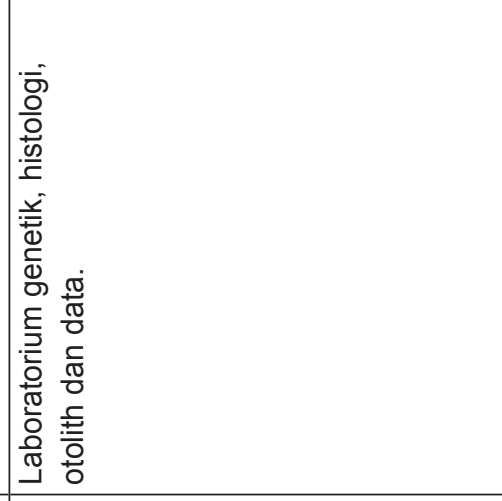 } & 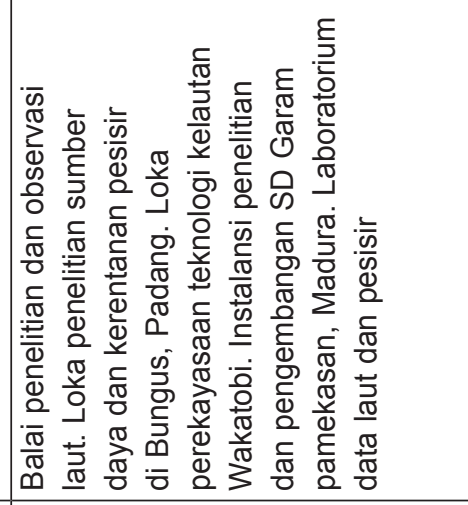 \\
\hline 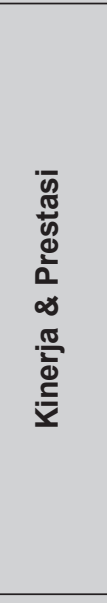 & 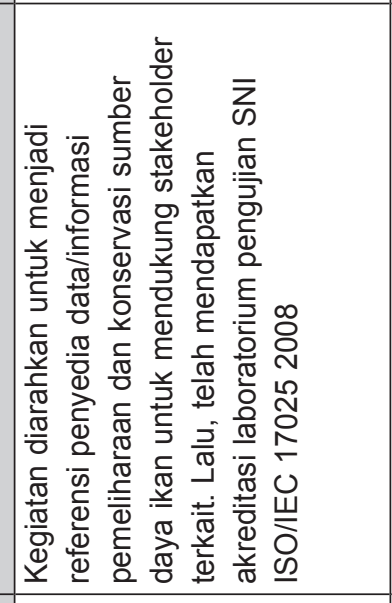 & \multicolumn{2}{|c|}{ 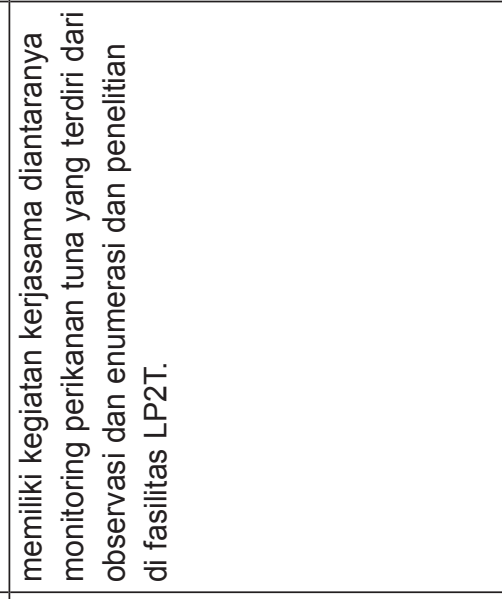 } & 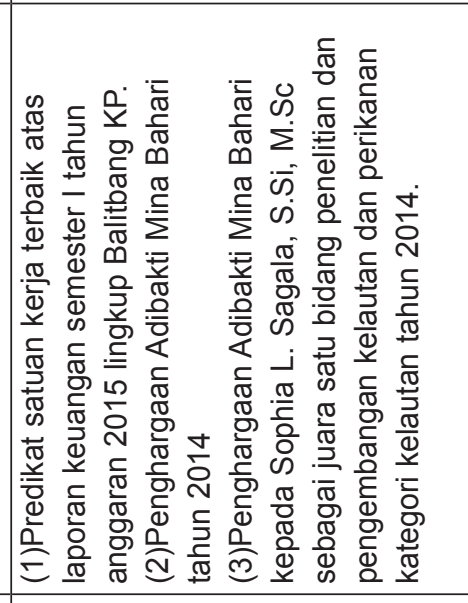 \\
\hline 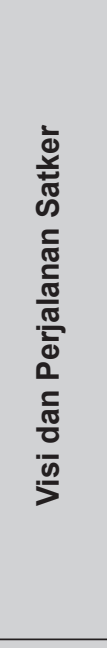 & 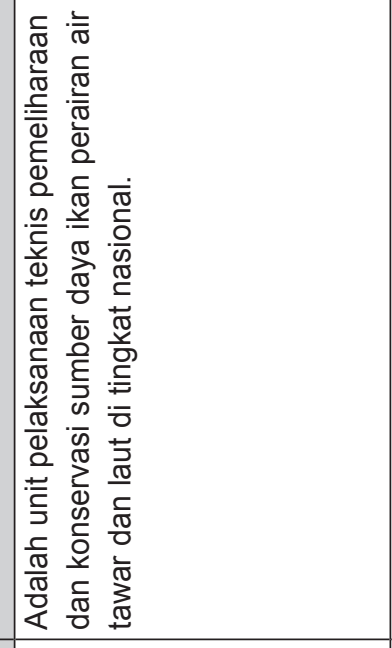 & 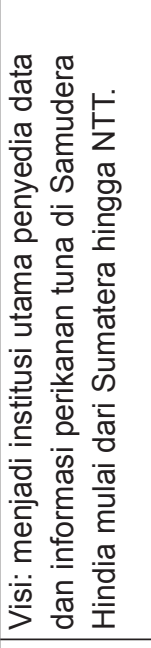 & 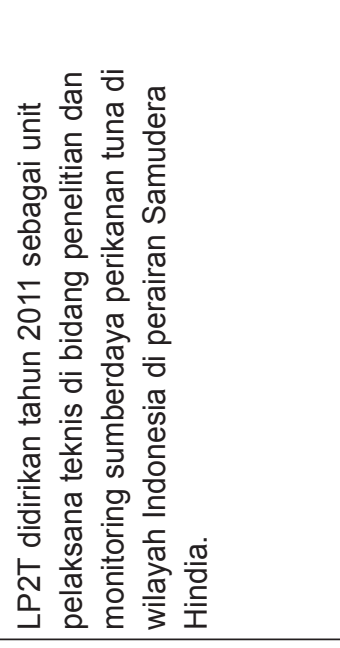 & 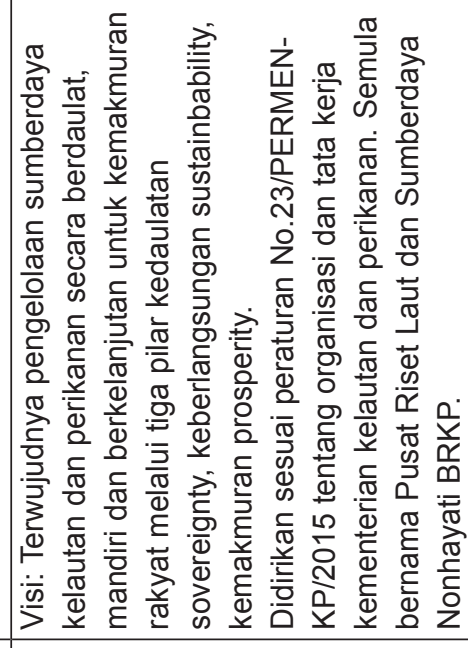 \\
\hline 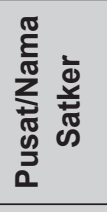 & 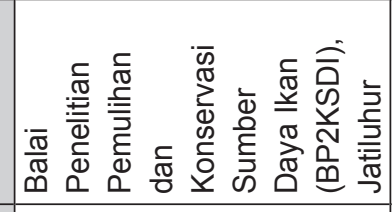 & 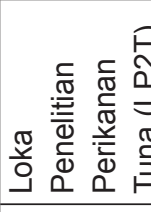 & & 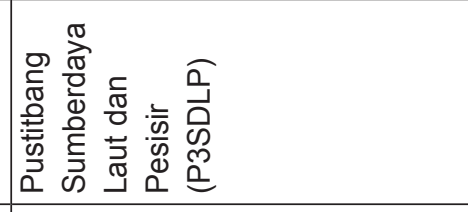 \\
\hline$\stackrel{0}{z}$ & $\stackrel{\sim}{i}$ & 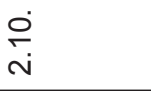 & & m \\
\hline
\end{tabular}




\begin{tabular}{|c|c|c|}
\hline 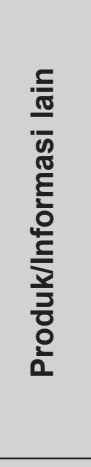 & 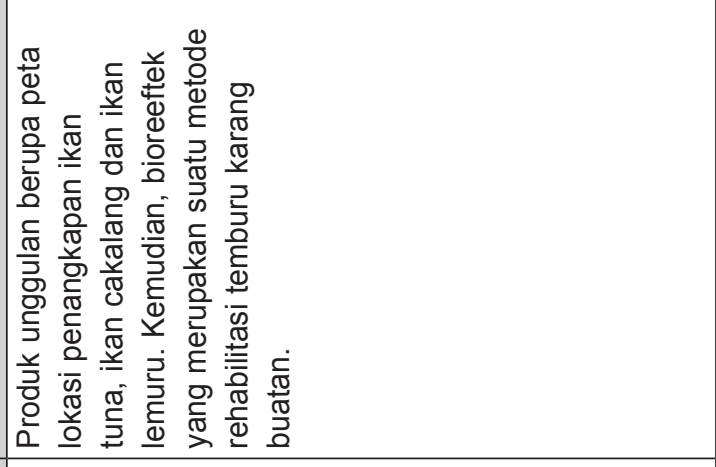 & 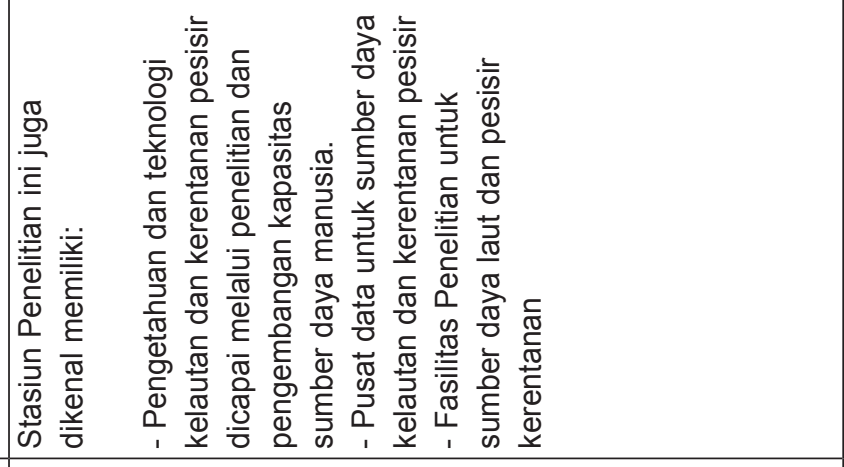 \\
\hline 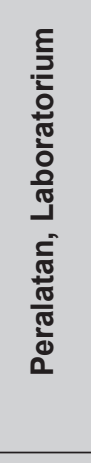 & & 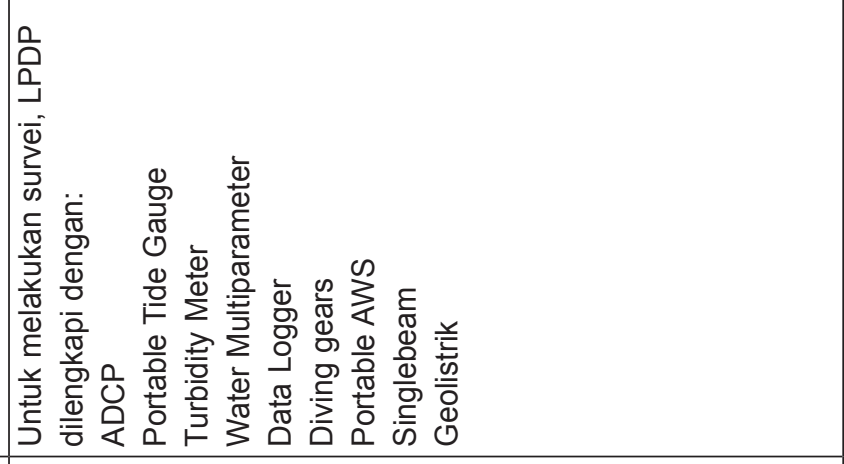 \\
\hline 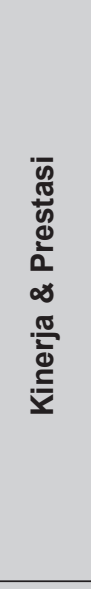 & 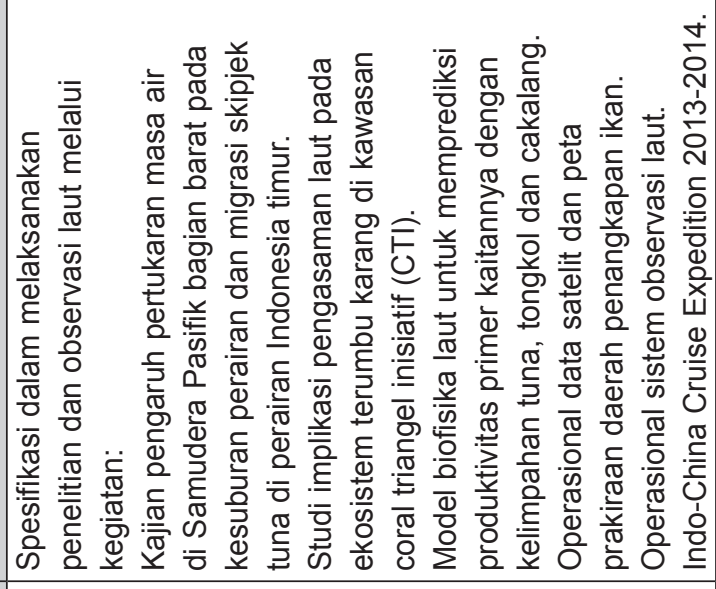 & 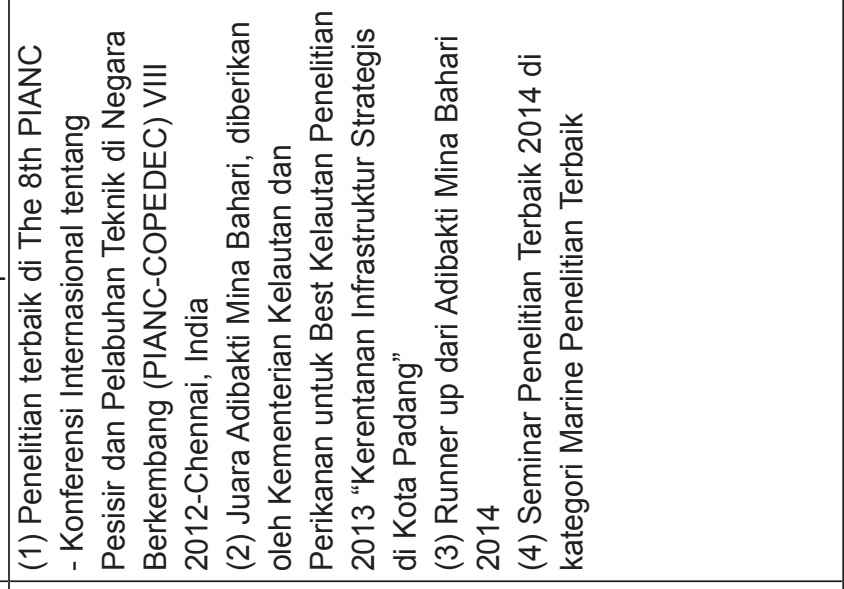 \\
\hline 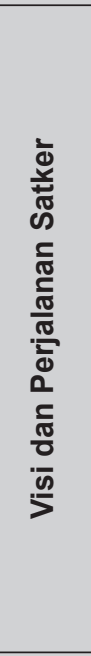 & 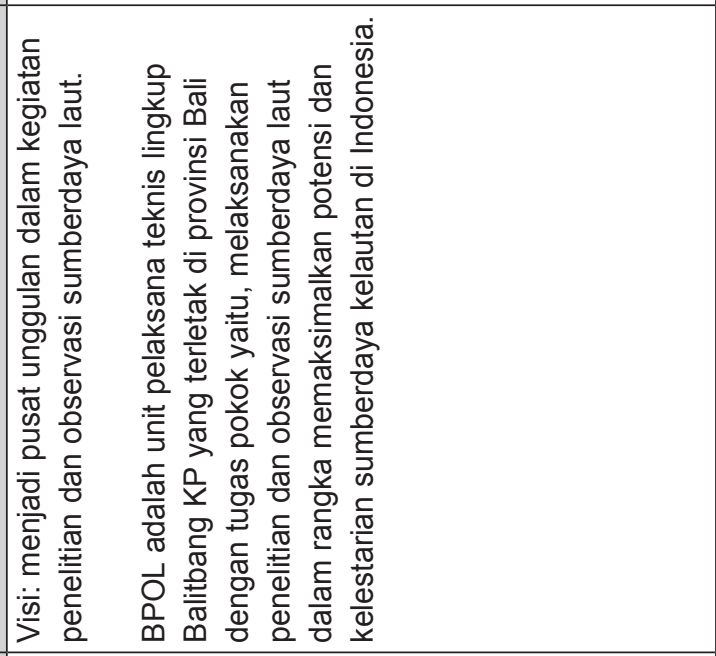 & 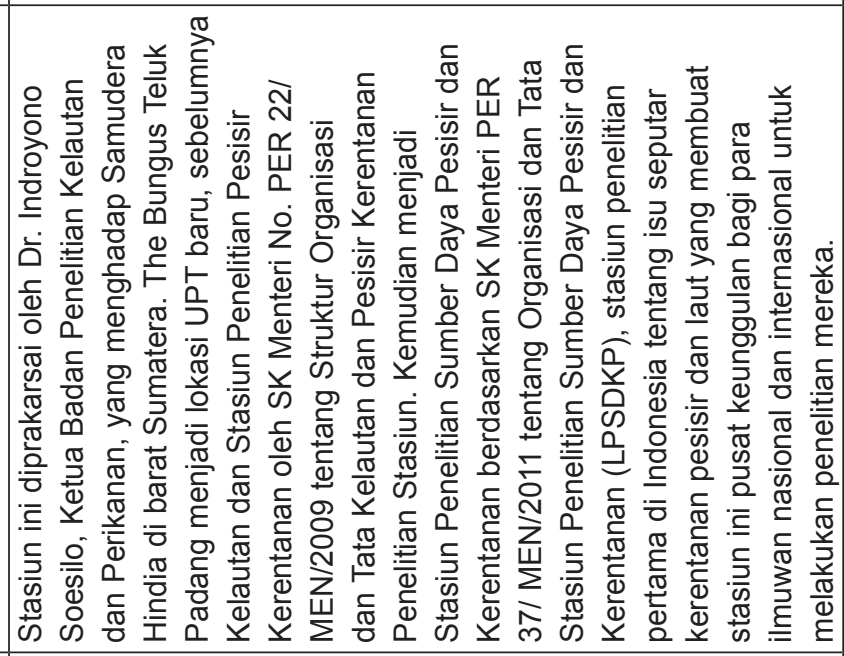 \\
\hline 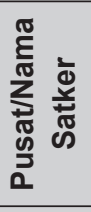 & 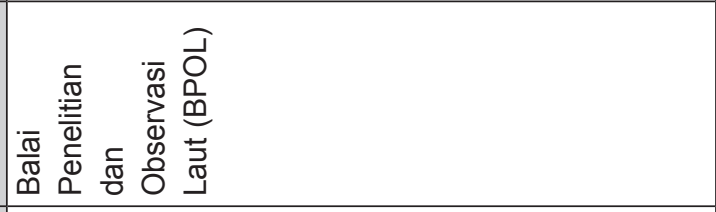 & 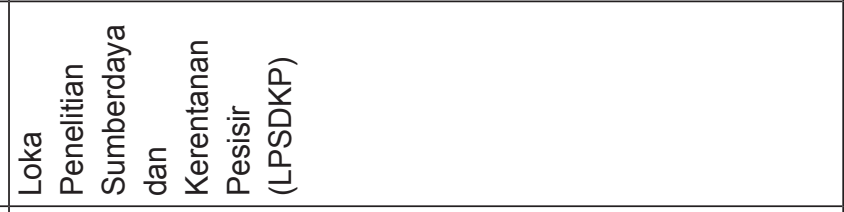 \\
\hline ì & $\dot{m}$ & ָׁ \\
\hline
\end{tabular}




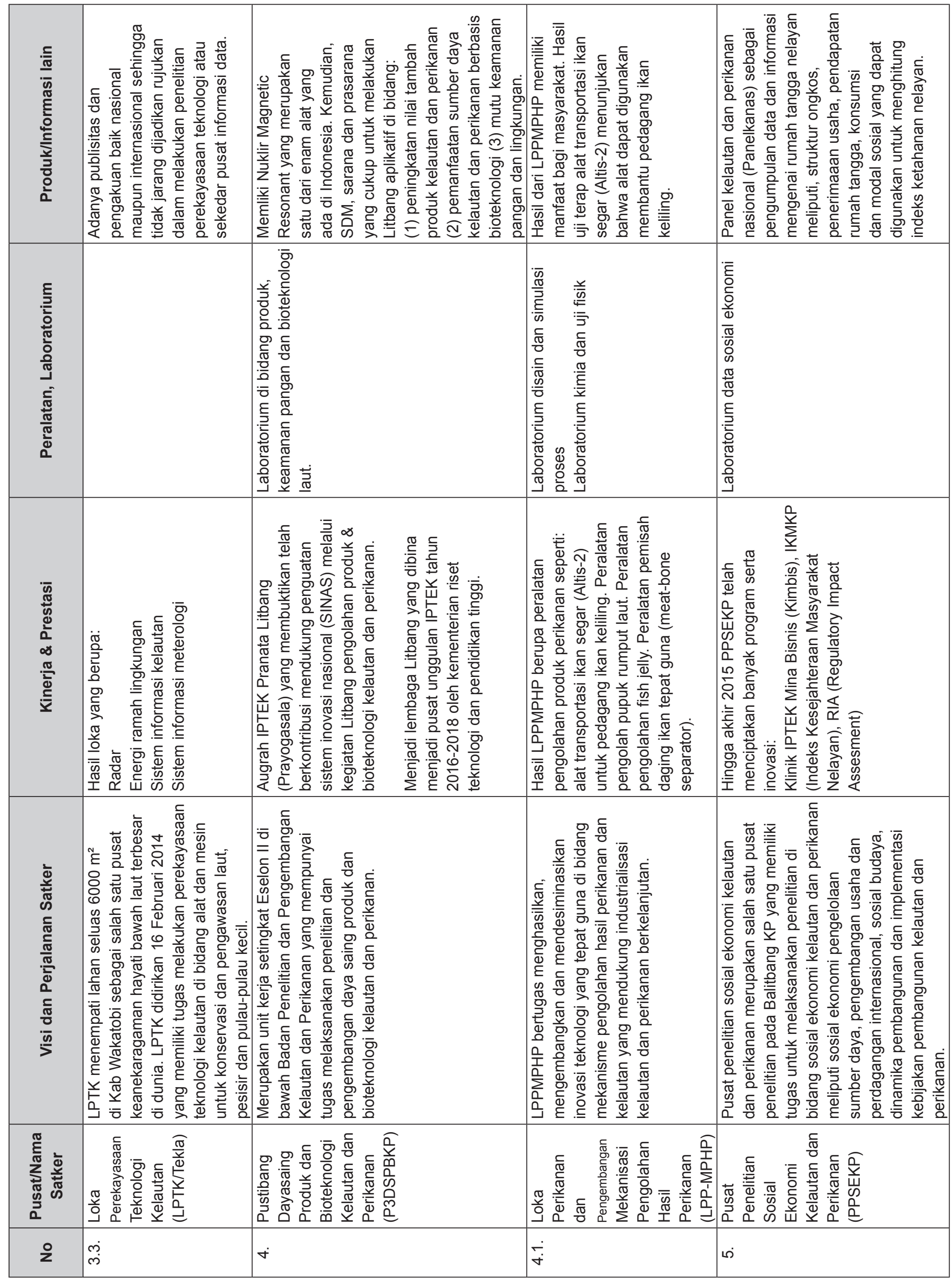

